\section{Instructor Strategies to Alleviate Stress and Anxiety among College and University STEM Students}

\author{
Jeremy L. Hsu* and Gregory R. Goldsmith
}

Schmid College of Science and Technology, Chapman University, Orange, CA 92866

\begin{abstract}
While student stress and anxiety are frequently cited as having negative effects on students' academic performance, the role that instructors can play in mitigating these challenges is often underappreciated. We provide summaries of different evidence-based strategies, ranging from changes in instructional strategies to specific classroom interventions, that instructors may employ to address and ameliorate student stress and anxiety. While we focus on students in science, technology, engineering, and mathematics, the strategies we delineate may be more broadly applicable. We begin by highlighting ways in which instructors can learn about and prepare to act to alleviate stress and anxiety. We then discuss how to better connect with students and build an inclusive, equitable, and empowering classroom environment. When coupled with strategies to change student evaluation and assessment, these approaches may collectively reduce student stress and anxiety, as well as improve student performance. We then discuss the roles that instructors may play in empowering students with skills that improve their time management, studying, and approach toward learning, with an eye toward ensuring their success across all their academic endeavors. We conclude by noting areas in which further research is needed to determine best practices for alleviating student stress and anxiety.
\end{abstract}

\section{INTRODUCTION}

Several recent measures have indicated increases in mental health challenges in U.S. college students (Eisenberg et al., 2013; Beiter et al., 2015; Lipson et al., 2018). In particular, a nationwide survey of undergraduate students in the United States identified stress ( $40 \%$ of all students) and anxiety (29\% of all respondents) as the two most common impediments to academic performance (American College Health Association [ACHA], 2019). Stress and anxiety are complex concepts, and their denotation has been the subject of considerable debate (Lazarus and Folkman, 1984). Stress can be described as an individual's perception that a situation exceeds their ability to cope and endangers their well-being, while anxiety is described as the ambiguous feelings that arise from unresolved stress (sensu Lazarus and Folkman, 1984; as described in Bamber and Kraenzle Schneider, 2016). It is important to note that studies in educational research do not always provide formal definitions for stress and anxiety, nor do they necessarily even distinguish between the two.

While stress and anxiety may differ, it is clear that both are major challenges facing college students. In fact, more than one-third of all college students report experiencing stress that impacted their academic performance within the past academic year (ACHA, 2019; Morey and Taylor, 2019), and students with high stress are more at risk of attrition or leaving college (Muller et al., 2017). In addition, student anxiety can also negatively influence persistence in the biology major (England et al., 2017, 2019). The prevalence of these mental health challenges is a complex issue that requires engaging stakeholders from across an institution, and there are undoubtedly many factors that can contribute to student anxiety and stress beyond academics. Here, we focus specifically on the role that instructors can play in supporting students and
Cynthia Brame, Monitoring Editor

Submitted Aug 17, 2020; Revised Jan 4, 2021; Accepted Jan 8, 2021

CBE Life Sci Educ March 1, 2021 20:es1

DOI:10.1187/cbe.20-08-0189

*Address correspondence to: Jeremy L. Hsu (hsu@chapman.edu).

() 2021 J. L. Hsu and G. R. Goldsmith. CBE-Life Sciences Education @ 2021 The American Society for Cell Biology. This article is distributed by The American Society for Cell Biology under license from the author(s). It is available to the public under an Attribution-Noncommercial-Share Alike 3.0 Unported Creative Commons License (http://creativecommons.org/licenses/ by-nc-sa/3.0)

"ASCB®" and "The American Society for Cell Biology $\circledR^{\prime \prime}$ are registered trademarks of The American Society for Cell Biology. 
mitigating their stress and anxiety, providing a review of evidence-based practices that instructors can use to lower student stress and alleviate anxiety.

The role of higher education instructors in mitigating student stress, anxiety, and mental health challenges is underexplored (Di Placito-De Rango, 2018). Although there have been a number of studies, reviews, and books that examine factors that may contribute to student anxiety and stress, as well as potential interventions that may help reduce anxiety in students (Hattie et al., 1996; von der Embse et al., 2013; Regehr et al., 2013; Ribeiro et al., 2018; Yusufov et al., 2019), many of those works do not specifically focus on college students or do not focus on the instructor. Instead, these reviews tend to emphasize broader programmatic steps that can be adopted by an institution that may not be directly applicable for an instructor. In contrast, our objective is to provide evidence-based strategies that can be implemented by new and experienced instructors to reduce their students' stress and anxiety and ultimately improve students' academic performance and quality of life. We provide these strategies in the context of our own experience as instructors in the life sciences and therefore in the context of science, technology, engineering, and mathematics (STEM) literature and disciplines; however, we expect that many of the approaches summarized here should be applicable to other academic disciplines. To organize our review, we focus these strategies into five main categories that span the arc of interacting with a student from the start to the end of a course and beyond:

1. Learning and preparing to act

2. Connecting with students

3. Building an empowering atmosphere in the classroom

4. Reducing testing anxiety

5. Promoting effective academic skills

In addition, we provide a summary of these strategies (Table 1) and a short list of recommended literature for instructors to read to learn more about these strategies (Box 1). In all these strategies, we recognize that instructors may feel unqualified or uncomfortable addressing such challenges and may be wary of exacerbating mental health concerns (White and LaBelle, 2019). We emphasize that our advice here does not suggest that instructors take the role of mental health professionals; clear boundaries must be established when interacting with students regarding issues of mental health more generally. However, we hope that these evidence-based strategies can help instructors become informed and improve their ability to act proactively and respond to such challenges.

\section{LEARNING AND PREPARING TO ACT}

In this first category, we describe the steps that instructors can take to familiarize themselves with the many ways that stress and anxiety can manifest in students, as well as the campus resources for helping students in crisis. Instructors, in part because of their frequent contact with students, can play a critical role as "first-line responders" in recognizing challenges, rendering support, and redirecting students to other resources (Di Placito-De Rango, 2018).

\section{Recognizing Underlying Mental Health Challenges}

Academic performance and the pressure to succeed (or, conversely, the fear of failing) are known drivers of stress and anxiety in college students (Beiter et al., 2015). Both stress and anxiety have been closely associated with depression and other mental health challenges as well as physical illness in college students (Kumaraswamy, 2013; Mahmoud et al., 2012; Rawson et al., 1994). These mental health challenges can manifest in many different forms, including depression and thoughts of, or attempts at, suicide (Garlow et al., 2008).

Although instructors cannot (and should not) serve as health professionals, instructors can learn about common mental health challenges relating to stress and anxiety. Instructors who familiarize themselves with and are aware of mental health challenges can better direct students to the proper resources and likewise will have greater insight into how to approach these conversations with students if and when they arise.

Many universities offer seminars or short trainings led by the campus health resources that are explicitly intended for instructors. While there is no replacement for seeking professional help, and some students may need more intensive mental health supports, these workshops provide instructors with basic training on how to provide support and identify students in need. Trainings can enable instructors to be more familiar with the range of potential mental health challenges students may be facing, guide instructors through how to hold conversations supporting students and referring them to mental health resources when needed, and provide a range of possible resources for instructors to be aware of. Trainings often include role-playing practice sessions to allow instructors to be more comfortable in conversations in which students approach an instructor and appear anxious, depressed, or suicidal. Trainings may also discuss the role of faculty as mandated reporters in connecting students in danger with additional resources. For those who wish to educate themselves further or whose campuses lack resources, the American College Health Association (www.acha.org) and the Jed Foundation (jedfoundation.org) are two organizations that provide accessible starting points. The more instructors become familiar with these underlying mental health challenges, the better prepared they are to appropriately respond and refer students to the proper resources when faced with a student in need.

\section{Know and Promote Campus Resources}

Instructors can familiarize themselves with various campus resources, such as where to refer students if they need mental health assistance, as well as the campus public safety office and emergency medical services. However, many universities also have an explicit protocol for contacting the office of student affairs (or equivalent) if an instructor is concerned about a student who is experiencing an emergency and/or needs more immediate mental health assistance. Having a list of phone numbers and addresses easily accessible can be helpful so that instructors can connect a student to the appropriate resources or contact such resources directly when appropriate if there is a student in need (e.g., if a student appears to be struggling, has abruptly changed their behavior, or has communicated major stressors, like a death in the family, with the instructor). Similarly, instructors should encourage students to use the resources available on campus. Common resources (albeit with different titles, depending on the institution) include counseling services, academic tutoring centers, and disability services. College students consistently report a poor understanding of what 
TABLE 1. A summary of the strategies that can be employed by instructors to reduce student stress and anxiety

\begin{tabular}{|c|c|c|}
\hline Category & Strategy & Summary of strategy \\
\hline Learning and preparing to act & $\begin{array}{l}\text { Recognize underlying mental health } \\
\text { challenges. } \\
\text { Know and promote campus resources. }\end{array}$ & $\begin{array}{l}\text { Become familiar with underlying mental health challenges, and } \\
\text { know how and when to refer students to campus resources if } \\
\text { needed. }\end{array}$ \\
\hline \multirow[t]{2}{*}{ Connecting with students } & $\begin{array}{l}\text { Use student names. } \\
\text { Empathize with students and provide } \\
\text { opportunities for interpersonal } \\
\text { connection. }\end{array}$ & $\begin{array}{l}\text { Take steps to learn student names, such as using name tents, and } \\
\text { connect with students to increase instructor immediacy. }\end{array}$ \\
\hline & Use humor. & $\begin{array}{l}\text { Use appropriate humor to promote a positive classroom atmo- } \\
\text { sphere. }\end{array}$ \\
\hline $\begin{array}{l}\text { Building an empowering } \\
\text { atmosphere in the } \\
\text { classroom }\end{array}$ & $\begin{array}{l}\text { Shape active-learning strategies to } \\
\text { minimize anxiety. } \\
\text { Be deliberate when forming student } \\
\text { groups. }\end{array}$ & $\begin{array}{l}\text { Be aware of some active-learning strategies (e.g., cold-calling) that } \\
\text { can increase stress and take steps to decrease anxiety when } \\
\text { using active-learning techniques, such as structuring groups } \\
\text { carefully or allowing students to form their own groups. }\end{array}$ \\
\hline & $\begin{array}{l}\text { Create an inclusive and equitable } \\
\text { classroom. } \\
\text { Choose words carefully. }\end{array}$ & $\begin{array}{l}\text { Be explicit about promoting a classroom environment where all } \\
\text { students are included and treated equally; be aware of and } \\
\text { avoid microaggressions or language that introduces a } \\
\text { stereotype threat. }\end{array}$ \\
\hline \multirow[t]{2}{*}{ Reducing testing anxiety } & Reduce or modify high-stakes testing. & $\begin{array}{l}\text { Build in alternate means of assessment to reduce high-stakes tests } \\
\text { that lead to high anxiety, or modify the structure of exams to } \\
\text { lower stress. }\end{array}$ \\
\hline & Perform classroom interventions. & $\begin{array}{l}\text { Use specific interventions, like having students write about their } \\
\text { anxiety, in order to reduce their stress and improve their } \\
\text { performance. }\end{array}$ \\
\hline $\begin{array}{l}\text { Promoting effective academic } \\
\text { skills }\end{array}$ & $\begin{array}{l}\text { Instill effective study habits and time } \\
\text { management skills. } \\
\text { Use metacognition. } \\
\text { Promote a growth mindset. }\end{array}$ & $\begin{array}{l}\text { Promote strong learning strategies and a growth mindset so } \\
\text { students know they can improve. }\end{array}$ \\
\hline
\end{tabular}

mental health resources are available to them, and instructors can play a role in increasing awareness (Zivin et al., 2009; Dobmeier et al., 2013). Even if they are aware of the resources, students may be hesitant to reach out due to a perceived stigma or other barrier (Eisenberg et al., 2009; Wu et al., 2017). Engaging students in conversation does not guarantee that they will seek additional help (Mitchell et al., 2012). Nevertheless, discussing these resources and encouraging students to use these support systems can ensure that more students experiencing stress, anxiety, or other mental health challenges are paired with the proper resources.

A range of other campus resources are often available to students to help alleviate stress and anxiety stemming from academic pressures. Many universities offer courses or workshops on academic skills, study strategies, and time management; different variants of these programs have been shown to promote student performance and retention and lower stress, as discussed later in the section on effective academic skills (Macan et al., 1990; Kimbark et al., 2017). Some universities also offer peer tutors who can assist with either course content or academic skills. Instructors can familiarize themselves with these resources, ensure that students in their classes are aware of these resources, and refer students to these support systems when needed.

\section{CONNECTING WITH STUDENTS}

In this category, we discuss several strategies that instructors can use to promote connections with students. Establishing

\section{BOX 1. An Annotated List of Additional Reading}

- Cooper and Brownell (2020): In this book chapter, Cooper and Brownell summarize the literature on how active learning impacts anxiety in the college science classroom and provide more information on how to best employ active-learning techniques while minimizing stress.

- Tanner (2013): In this synthesis paper, Tanner provides a summary of strategies instructors can take to improve engagement and equity in the classroom. While this article was not written in the context of reducing stress and anxiety, it provides direct and useful strategies for building an inclusive classroom, and several of the strategies outlined (learn or have access to students' names, do not judge responses, use praise with caution, etc.) may increase instructor immediacy. Promoting an empowering classroom atmosphere and increasing instructor immediacy may lower stress and anxiety.

- Hodges (2018): In this article, Hodges discusses different types of group work in the classroom, group formation, how students learn in groups, and why some groups fail. This article provides insight into how instructors can most effectively manage group work, thus lowering stress.

- Regehr et al. (2013): In this article, Regehr and coauthors provide a review and meta-analysis of interventions to lower stress in college students. While most of the interventions are broader campus-level interventions that are not realistically implemented in a classroom by an instructor, the article provides great insight into what techniques are most effective at lowering stress in college students. 
these connections increases instructor immediacy, the perception of relational closeness and connection between the student and the instructor (LeFebvre and Allen, 2014). This can make students more comfortable in class and more willing to engage with the instructor both inside and outside class (Cooper et al., 2017). Unsurprisingly, it has been demonstrated in both nonSTEM and STEM classes that student anxiety decreases as instructor immediacy increases (Williams, 2010; Mazer et al., 2014; Kelly et al., 2015). Thus, while there are only a limited number of studies directly examining the impact of the strategies we describe here on student stress or anxiety, each strategy has been shown to promote instructor immediacy and thus may help mitigate student anxiety.

\section{Use Student Names}

One of the simplest steps that instructors can take to connect with students and increase instructor immediacy may be to learn and use their preferred names and pronouns. While learning names may be more challenging for instructors teaching large classes, there are several strategies that instructors can use to learn student names more effectively. For instance, many institutions offer photo rosters to help instructors recognize and learn student names. Similarly, an increasing number of institutions now allow students to record their name out loud, helping instructors pronounce names more easily. Cooper et al. (2017) find that using name tents-pieces of paper on which students write and display their preferred names-helped dramatically increase the perception that the instructor knew student names in a high-enrollment biology class, which led students to report positive impacts on their attitudes, behaviors, and perceptions of the course. For instance, many students felt more valued, more invested in the course, and more comfortable communicating with the instructor and reaching out for help; they also stated that the use of names made them feel like the instructor cared about them and helped establish better student-instructor relationships (Cooper et al., 2017). These are all attributes that promote increased instructor immediacy and are thus associated with reduced anxiety (Jaasma and Koper, 1999; Baker, 2004; Creasey et al., 2009). Notably, the results reported by Cooper et al. (2017) are despite the fact that the instructor did not actually know the names of all students. Instructors can also ask students to write preferred pronouns on their name tents if the students are comfortable doing so; this optional use of pronouns provides an opportunity for lesbian, gay, bisexual, transgender, queer, intersexual, or asexual (LGBTQIA) students to convey their preferred pronouns for both the instructor and their classmates if they so wish, thus creating a more inclusive environment and potentially lowering their stress (Cooper et al., 2020). Students have also reported that instructors learned their names through interactions during class, immediately before and after class, during office hours, and in other conversations outside class time (Cooper et al., 2017). However, instructors should be cognizant that the use of names in some contexts may increase anxiety; students in K-12 classrooms have reported anxiety if instructors mispronounce their names (Kohli and Solórzano, 2012), and the use of names for random cold-calling can also increase anxiety (Cooper et al., 2018a; Waugh and Andrews, 2020). Beyond using name tents, we have found that arriving a few minutes before the start of class to allow for time to set up, as well as to check in and greet students, allows us to more effectively connect with students and learn their names.

\section{Empathize with Students and Provide Opportunities for Interpersonal Connection}

In addition to learning and using student names, instructors should work to empathize with students and provide opportunities for interpersonal connection; these attributes have been shown to increase the perception of students that instructors care about them (Teven, 2001), which has been shown to be associated with increased instructor immediacy (Schutt et al., 2009). In addition to the informal conversations that occur in the few minutes before and after each class, sharing personal stories can also enliven the classroom and help counter student perceptions about the course, topic, and/or instructor. The use of "noncontent instructor talk" in class-defined as any instructor language that does not directly convey the course concepts-has been documented as a way to build the relationship between the instructor and student, establish classroom culture, and increase instructor immediacy (Seidel et al., 2015). Our own experiences suggest that noncontent instructor talk outside class (e.g., during office hours or individual meetings with students) may also provide the same benefits. By sharing certain personal experiences, we enable interpersonal connection and may promote a growth mindset by illustrating our own growth when we were students (as discussed later). For instance, when faced with students who struggle on a quiz or exam, we often bring up an example of an undergraduate exam gone wrong from our own experiences as students. We then discuss how we changed our study habits and how we improved following that experience. Sharing these stories encourages students and likely promotes greater instructor immediacy that may lower anxiety by showing that it is possible to recover from a poor test performance.

\section{Use Humor}

The use of appropriate humor in class can also lessen anxiety in the classroom (Wanzer and Frymier, 1999; Cooper et al., $2018 \mathrm{~b})$. While there are many categories of inappropriate humor (such as ones that marginalize or disparage groups of students) that can damage student-instructor relationships, the use of appropriate humor can be used to strengthen the student-instructor relationship and establish a more positive classroom climate (Bekelja Wanzer et al., 2006; Cooper et al., 2020). In addition, the use of humor can also increase student perceptions of learning as well as their motivation and willingness to engage in class (Wanzer and Frymier, 1999; Neumann et al., 2009; Banas et al., 2011). Embedding humor into exams and other assessments has also been shown to lead to lower stress and increased perception of exam performance by students (Berk, 1996, 2010).

\section{BUILDING AN EMPOWERING ATMOSPHERE IN THE CLASSROOM}

While connecting with students is important, it is equally critical to build a classroom atmosphere that empowers all students to feel comfortable learning, which may correlate with reduced student anxiety in the biology classroom in some contexts (Cooper and Brownell, 2016). There are several strategies that instructors can take to promote such a dynamic. 


\section{Shape Active-Learning Strategies to Minimize Anxiety}

The benefits of active-learning strategies have been well documented, including increased learning for students, a decrease in the achievement gap for identities historically underrepresented in the sciences, and improved attitudes and perceptions toward science (Armbruster et al., 2009; Haak et al., 2011; Freeman et al., 2014; Theobald et al., 2020). However, recent research has indicated that many active-learning techniques can also increase student anxiety or the perceptions of student anxiety (England et al., 2017; Cooper et al., 2018a; Cooper and Brownell, 2020; Downing et al., 2020) and that students employ both adaptive and maladaptive strategies to cope with this anxiety (Brigati et al., 2020). Ultimately, students with high anxiety may even learn less in an active-learning classroom (Cohen et al., 2019). Some techniques, such as cold-callingasking a student to share a response with the class without the student volunteering - have been identified as producing particularly high anxiety in students (England et al., 2017; Cooper and Brownell, 2020; Waugh and Andrews, 2020). Even modifying common techniques, such as cold-calling, to reduce apprehension may still lead to increased student anxiety as compared with not using such techniques (Broeckelman-Post et al., 2016). In addition, different demographics of students (e.g., underrepresented students and students who speak English as a second language) may feel disproportionate amounts of stress and anxiety in an active-learning classroom (Mak, 2011; Freeman et al., 2014; Cooper and Brownell, 2016). Similarly, such active learning has the potential to disproportionately impact underrepresented students; for instance, Cooper and Brownell (2016) find that students in biology classes who are LGBTQIA report that in-class group work, particularly if they are not allowed to choose their own groups, can increase their stress and anxiety, given that they are faced with the challenge of potentially working with students who are not accepting of their identities.

While the diversity of active-learning techniques makes it challenging to generalize about active learning and classroom anxiety, there are a few active-learning techniques that may be less stressful than others. For instance, Cooper et al. (2018a) find that some types of active-learning strategies, such as clicker questions and group work, have the potential to help lower anxiety levels for some students. Ultimately, few studies to date have investigated the impact of active-learning interventions on reducing anxiety. While none of these studies suggest that instructors move away from active-learning techniques, given their benefits to student learning and retention, instructors can take steps to minimize the stress and anxiety often associated with these techniques by explaining the rationale behind their pedagogical techniques, allowing students to form their own groups, and providing students the time to think individually and share with partners before being asked to share with the class (England et al., 2017; Cooper et al., 2018a). These steps can also increase trust in the instructor in an active-learning class, which has been shown to lead to increased student performance (Cavanagh et al., 2018), and would likely promote a more comfortable classroom atmosphere. While the term "active learning" encompasses a wide range of possible techniques in biology education and STEM education more generally (Driessen et al., 2020), instructors can use evidence-based guides and frameworks to aid their implementation of active learning and their response to student feedback (e.g., Allen and
Tanner, 2005; Seidel and Tanner, 2013; Stains and Vickrey, 2017). Our own experiences align, with several students expressing to us in past courses that while they were initially resistant to some of the active-learning techniques we implemented in class, hearing the pedagogical justification and seeing the results made them more accepting of these techniques.

\section{Be Deliberate when Forming Student Groups}

There is a growing body of empirical studies examining student group work and its impact on learning and attitudes (Jensen and Lawson, 2011; Chang and Brickman, 2018; Hodges, 2018).

While the formation of groups is highly context dependent (e.g., size of class, lower division or upper division, duration of group work), several studies have found that student learning and perceptions of learning increase, and anxiety decreases, when students are familiar with and comfortable sharing with their group mates (Theobald et al., 2017; Downing et al., 2020). Student anxiety is often driven by the fear of negative evaluation by peers and instructors (Watson and Friend, 1969; Weeks et al., 2005; Downing et al., 2020), and thus instructors can take steps to promote student familiarity and comfort with their groups. These include activities that provide an opportunity for students in groups to get to know one another and to establish group norms (Chapman and Auken, 2001). Students have also reported more positive group experiences with increased structure in group work (Theobald et al., 2017; Chang and Brickman, 2018). Thus, instructors may be able to lower student stress by assigning roles for students in groups; providing clear expectations with specific goals, objectives, and deadlines; and structuring activities so that students bring different pieces of expertise to the project.

Instructors may also allow students to choose their own groups, depending on the course context. Doing so can lessen stress and anxiety, particularly among students who may not wish to disclose parts of their identities (Cooper and Brownell, 2016). Allowing students to choose their own groups can also lessen fear of negative evaluation by their peers and thus decrease stress (Cooper and Brownell, 2020; Downing et al., 2020). However, instructors should be aware that doing so may increase stress and anxiety for some students, such as those who do not readily find a group (Rosser, 1998; Strauss et al., 2011; Henning et al., 2019; Juvonen et al., 2019).

Our own experience with group work affirms the complicated nature of forming student groups. Our best outcomes often come from forming groups around an affinity for a theme or topic that will be pursued for the project (e.g., a group of students all interested in doing a final project focused on genetics). We have also observed that allowing groups to remain consistent for a longer period of time (e.g., an entire unit or a semester-long project) can allow for group norms and foster a sense of community in the classroom that also extends outside the classroom, with students forming social networks with their groups and also relying on their partners for studying. Instructors may wish to refer to the evidence-based guide to group work from Wilson et al. (2018), which provides further context on the formation of groups.

\section{Create an Inclusive and Equitable Classroom}

Because student anxiety is often driven by fear of negative evaluation, fostering an inclusive and equitable classroom 
atmosphere where students are comfortable with being wrong can decrease student anxiety and stress and promote a more inclusive classroom (Cooper and Brownell, 2020; Downing et al., 2020). Downing et al. (2020) find that student fear of negative evaluation may be reduced by allowing students to work in groups with other students whom they know (see previous section), providing a chance for students to talk to their classmate before sharing with the class (referred to as "warm calling"), and framing errors as part of the learning process. Positive error framing can reduce stress and lead to both improved metacognition and learning for the student (Steele-Johnson and Kalinoski, 2014; Downing et al., 2020). If a student does perform poorly, Henry et al. (2019) outline a theoretical framework for how students can appropriately cope (e.g., problem solving, support seeking, and cognitive restructuring); by encouraging student ownership over their own learning and providing support, instructors may lessen the impact of the failure, promote future improvement, and ultimately alleviate stress.

\section{Choose Words Carefully}

Instructors can be cognizant of their choice of language and avoid microaggressions that may either consciously or subconsciously lead to some students not feeling welcome or included (Harrison and Tanner, 2018). Microaggressions-directly or indirectly speaking negatively about student identities-can make students feel unwelcome and thus elevate stress and contribute to anxiety (Harrison and Tanner, 2018). In contrast, the use of "microaffirmations"-any nonobvious verbal or nonverbal cues to demonstrate kindness-can counteract the impact of microaggressions and promote student persistence (Estrada et al., 2019). Such microaffirmations have been suggested to lower stress in certain populations of college students, such as first-generation students (Ellis et al., 2019), perhaps by alleviating a sense of isolation that can be associated with stress and anxiety (Harrison and Tanner, 2018).

Instructors can similarly reduce stereotype threat, that is, the "risk of confirming a negative stereotype," or an association/ expectation of conforming to a preconceived notion about a certain group of individuals (Steele and Aronson, 1995). Stereotype threat has been shown to increase student anxiety (Bosson et al., 2004; Osborne, 2007) and negatively impact student performance and achievement (Osborne, 2001; Cadinu et al., 2003). In addition to eliminating language that promotes stereotype threat, instructors can also perform specific interventions to mitigate stereotype threat. Seidel et al. (2015) posit that some types of noncontent instructor talk can help reduce stereotype threat. For instance, explicitly delinking the often-perceived association between exams and intelligence can decrease the impact of stereotype threat (Croizet and Claire, 1998; Spencer et al., 1999; Binning et al., 2020). Similarly, Johns et al. (2005) find that explicitly teaching about stereotype threat can help reduce the negative impacts of such stereotype threat; in their study, an intervention in which the instructor explained the idea of stereotype threat to women before those women took a math exam led to lower anxiety and higher performance.

In contrast to the negative impacts of stereotype threat, interventions that promote values affirmation-the process of positively reinforcing values important to students-can counter the effects of stereotype threat (Jordt et al., 2017). Values affirmation may also lower stress levels (Creswell et al., 2005), though some specific values affirmation interventions may not alleviate levels of anxiety (Czech et al., 2011; Peters et al., 2017). Despite this, values affirmation has been found to increase performance and reduce achievement gaps (Cohen et al., 2006; Miyake et al., 2010; Freeman et al., 2014; Peters et al., 2017). Even simple interventions that ask students to describe their values and how they practice and demonstrate these values in everyday life can be beneficial for students (Jordt et al., 2017).

\section{REDUCING TESTING ANXIETY}

Exams and tests can often be a source of stress and anxiety for students. In this section, we first describe structural changes that instructors can make to such assessments to lower stress and anxiety and then describe interventions that can be used to lower anxiety before or during such assessments.

\section{Reduce or Modify High-Stakes Testing}

High-stakes testing has been known to cause anxiety in students across a diversity of settings (Cizek and Burg, 2006; Kruger et al., 2007). In addition, there is evidence that women and underrepresented students may be disproportionately disadvantaged by such high-pressure exams (Ballen et al., 2017). Test anxiety can also contribute to increased student perceptions of difficulty and lower academic performance (England et al., 2019). As such, if instructors can reduce or eliminate high-stakes testing whenever possible, then this may reduce student anxiety (Putwain, 2008). For example, instructors can add smaller-stakes quizzes to reduce the proportional weight of exams as well as to create a means for formative assessment that informs both the instructor and learners. In addition, instructors can implement schemes to reward improvement over time (e.g., Bailey et al., 2017) or drop the lowest quiz or exam score. This approach lowers the potential impact of each individual assessment. Finally, instructors can explore alternate means of assessments beyond high-stakes testing, such as problem sets, essays, and lab reports (Ballen et al., 2017). Beyond the potential to reduce stress, using a diversity of methods for assessments (and thus lowering the weight of exams) has been shown to reduce the achievement gap of females in biology on both exams and the course as a whole (Ballen et al., 2017).

In addition, multiple studies demonstrate that open-book exams, or exams wherein students can bring in a "cheat sheet" with notes, can lower student stress (Durning et al., 2016; Erbe, 2007; Gharib and Phillips, 2012). However, the impacts of modifying exams to allow notes on student learning is unclear; while some studies report some improved learning gains or no impact on student learning or performance (Sato et al., 2015), other studies have found negative consequences on learning, retention, and student motivation (Moore and Jensen, 2007; Durning et al., 2016).

\section{Perform Classroom Interventions}

There are also several interventions that instructors can implement to help reduce student anxiety and/or increase student performance for an exam or a course. For instance, concept mapping has been found to lower student anxiety about the learning of biology, a benefit attributed to increased 
metacognition, as discussed elsewhere (Okebukola and Jegede, 1989; Jegede et al., 1990). In addition, asking highly anxious students to write about their testing worries immediately before an exam has repeatedly been demonstrated to help counter the expected negative impact of this anxiety on their test performance (Frattaroli et al., 2011; Ramirez and Beilock, 2011; Park et al., 2014). Similarly, several studies on stress reappraisal, the guiding of students to perceive stress and anxiety as beneficial given the possibility of increased focus and attention, have also been shown to both decrease anxiety and increase exam performance (Jamieson et al., 2013; Jamieson et al., 2016). In sum, these interventions have been shown to increase student performance for all students, including both low- and high-anxiety students (Harris et al., 2019). Instructors can either implement these interventions or let students know of the relevant research if they struggle with testing anxiety. Similarly, instructors can use published interventions relating to these themes that have been successfully implemented in a variety of courses (Doherty and Wenderoth, 2017; Harris et al., 2019). Finally, there are also a number of more general interventions that instructors can promote to lower stress, such as providing access to "comfort" or therapy dogs before an exam (Barker et al., 2016; McDonald et al., 2017; Schroder et al., 2017; Trammell, 2017; Jarolmen and Patel, 2018), or encouraging students to attend mindfulness and meditation classes (Bamber and Kraenzle Schneider, 2016).

\section{PROMOTING EFFECTIVE ACADEMIC SKILLS}

The strategies that have been described thus far are implemented by an instructor to reduce student stress and anxiety. However, there are many academic skills and strategies that a student could use to lower stress and anxiety; these strategies can therefore be implemented directly by the student in any course. In this section, we describe strategies that instructors can recommend to their students to improve time management and study skills, as well as promote students' own thinking about how they learn and their mindset toward the process of learning. While we acknowledge that instructors can also recommend ways in which students can cope with (i.e., manage) stress and anxiety, our intent here is to discuss strategies that instructors can instead take to prevent student stress and anxiety.

\section{Instill Effective Study Habits and Time Management Skills}

Ineffective study habits and time management have been found to correlate with anxiety and lower student performance, and thus there have been calls for instructors to facilitate development of these skills in order to lower student anxiety (Wittmaier, 1972; Bruch, 1981; Macan et al., 1990; Nonis et al., 1998; Cizek and Burg, 2006). Students may not be aware of how to study effectively, and thus instructors can promote these study strategies by discussing them with their classes. These strategies include 1) explicitly discussing the use of learning objectives with students and modeling the writing of a question based on a learning objective (Osueke et al., 2018); 2) suggesting that students retake past quizzes, exams, and assessments and reflect upon their performance (Walck-Shannon et al., 2019); 3) teaching students how to self-evaluate their own work (Osterhage et al., 2019); 4) guiding students toward self-regulated learning, wherein they set goals and monitor progress toward those goals (Sebesta and Bray Speth, 2017); 5) encouraging group studying, so students can clarify concepts with peers (Kritzinger et al., 2018); and 6) promoting regular and spaced-out study time in preparation for tests (Roediger and Karpicke, 2006).

Similarly, targeted programs to promote time management in college students have lowered their stress and anxiety (Häfner et al., 2014a,b; Aeon and Aguinis, 2017). The core elements of these interventions include prioritizing, goal setting, strategy development, daily planning, and the establishment of monitoring and reward structures as achieved by a series of self-reflection questions followed by a planning exercise (Häfner and Stock, 2010). Such interventions may be particularly useful for reducing procrastination and time discounting on larger or more long-term activities (Koch and Kleinmann, 2002). We regularly implement brief self-reflection exercises in the classroom, often focused on daily planning that includes the explicit incorporation of rewards that are also expected to reduce stress and anxiety (e.g., going to the gym to exercise after finishing an assignment).

\section{Use Metacognition}

Multiple studies have indicated that promoting metacognition, a process in which students think about and reflect upon their own learning, can lead to reductions in test and course anxiety (Alaiyemola et al., 1990; Everson et al., 1994; Matthews et al., 1999; Spada et al., 2006). Students generally need to be prompted to deliberately engage in metacognition, and instructor assistance may be needed to guide student thinking about studying, particularly for students earlier in their college careers (Stanton et al., 2019). For instance, instructors can implement exam wrappers, a questionnaire usually provided to students after an exam that asks them to reflect on their studying, preparation, and performance on the exam (Pate et al., 2019). The use of exam wrappers may lead to increased knowledge of cognition and higher performance (Gezer-Templeton et al., 2017; LaCaille et al., 2019; Langdon et al., 2019; Edlund, 2020). Instructors may also choose to use "enhanced answer keys" with reflective metacognitive questions embedded to deliberately prompt student metacognition (Sabel et al., 2017). Similarly, instructors can implement such metacognitive questions into homework or problem sets or ask students questions that promote metacognition during individual or class meetings. For instance, as instructors, we regularly prompt students to use note cards to reflect on what they did well in the past week and what they wish to improve on in the coming week as a simple method for promoting metacognition.

\section{Promote a Growth Mindset}

Language that promotes a growth mindset, or the belief that skills, personality, and intelligence can change and be improved, has been linked to greater academic achievement and improved grades (Claro et al., 2016; Yeager et al., 2019). This contrasts with a fixed mindset, whereby students believe that their intellectual abilities are immutable (Dweck, 2000; Claro et al., 2016). Likewise, fostering a growth mindset has been shown to mitigate stress and anxiety in psychological studies (Schleider and Weisz, 2016, 2018; Schroder et al., 2017). While the literature examining a growth mindset and the impact on stress in 
the classroom is sparse, instructors can have a direct influence on students' perceptions of a growth mindset (Powers, 2015). Instructors can incorporate short messages promoting a growth mindset in the classroom and encourage further growth and improvement in students. We often praise students on improvement and encourage students who struggle to come talk to us, reflect on their learning, and then improve on the next assessment. In addition, course policies that reward increased learning may also promote a growth mindset, reducing anxiety while fostering and maintaining student motivation. For example, Fernandez (2020) describes promoting a growth mindset by structuring grading around mastery, while providing students a second chance at answering questions on an exam.

\section{OPPORTUNITIES FOR FUTURE RESEARCH}

While the relationships between student stress and anxiety and academic performance are relatively well established, there remain many opportunities to establish and strengthen our understanding of what practices instructors can adopt to decrease stress and anxiety. We highlight three main areas.

\section{How Applicable Are These Strategies and Interventions for Reducing Stress and Anxiety among Different Demographics?}

Students report different levels of stress and anxiety depending on gender, ethnicity, and sexual orientation (Eisenberg et al., 2013; Posselt and Lipson, 2016). It is not clear that a strategy to reduce stress and anxiety studied among one student demographic will be applicable to another. Moreover, there appear to be systematic biases in the current literature. For instance, a recent analysis of biology education research found biases in study populations, with the majority of studies focusing on undergraduate students at research-intensive institutions (Lo et al., 2019). Relatively few biology education studies have focused on community college and transfer students, despite those students making up nearly half of postsecondary biology students in the United States and generally comprising a more diverse population than students at research-intensive institutions (Schinske et al., 2017). We found only a few studies that focused explicitly on studying stress or anxiety in these populations (Powers, 2015; Kimbark et al., 2017; Downing et al., 2020). Future research is needed to examine the generalizability of these strategies among different student populations and among different identities more generally.

\section{How Applicable Are These Strategies and Interventions for Reducing Stress and Anxiety in Different Contexts?}

Students also report different levels of stress and anxiety depending on STEM major (May and Casazza, 2012). It is not clear that a strategy to reduce stress and anxiety studied in one discipline will be applicable to another or that the strategy will be relevant for different concepts within a discipline. For instance, some of the strongest evidence regarding strategies that can reduce anxiety and increase performance (e.g., informing certain groups about stereotype threat, using humor to connect with students, expressive writing before taking an exam) arise from studies carried out in mathematics and statistics courses (Spencer et al., 1999; Johns et al., 2005; Neumann et al., 2009, p. 200; Williams, 2010; Park et al., 2014). Each of these strategies could be applied in biology; however, their efficacy generally remains untested. Similarly, if effective, the strategies could also be applied to reduce math anxiety in the context of the biology classroom (e.g., Madlung, Bremer, Himelblau, and Tullis, 2011). Future research is needed to examine whether strategies applied in one context will work in another context. When combined with the need to consider how different student identities respond to a given strategy, this presents a significant challenge for the field moving forward.

\section{What Strategies Have a Weak or Nonexistent Evidence Base?}

In many cases, the strategies that we identify here currently lack evidence for direct linkages with reductions in stress and anxiety. For instance, the use of student names is predicated on the linkage between name use and instructor immediacy. There is a need for additional research that explicitly measures student stress and anxiety as a function of different classroom interventions, even if only ancillary to the primary purpose of the study. This research should strive to adopt more explicit definitions of stress and anxiety, although we recognize that the many conceptualizations of stress and anxiety make this quite challenging (Lazarus and Folkman, 1984). In addition, we identified several strategies that are likely to be related to student stress and anxiety but have no clear evidence base. For instance, many students perceive office hours negatively, with students often citing apprehension about using office hours and viewing them as a last resort (Smith et al., 2017). Despite the stress and anxiety that can be created by office hours, research on best practices remains limited and presents an area for future research.

\section{CONCLUSION}

Some stress and anxiety are likely unavoidable, and students can also learn various coping mechanisms through the adoption of healthy academic (e.g., problem solving, information seeking, emotional regulation, etc.; Henry et al., 2019) and self-care habits (e.g., sufficient sleep, getting exercise, identifying a supportive community of friends; Myers et al., 2012). However, we have focused here on identifying evidence-based strategies that instructors can employ to try to reduce student stress and anxiety so that students can reach their full potential in the classroom. These strategies span a range of approaches, from modifying instructional techniques to empowering students with different mindsets and tools that they can use to alleviate stress. Instructors can pick and choose among these strategies depending on context, but should always think about ways to assess their efficacy. In that sense, our review also exposes the need for new studies that explicitly link instructional techniques with student stress and anxiety and that identify how those relationships vary among STEM disciplines and across diverse student demographics.

\section{ACKNOWLEDGMENTS}

G.R.G. is supported by the Grand Challenges Initiative at Chapman University. We thank L. Sanchez for assistance with references. We thank the reviewers and handling editor for valuable suggestions and feedback. In addition, we thank D.S. Newman and the faculty and staff of the Grand Challenges Initiative for helpful comments that improved this essay. 


\section{REFERENCES}

Aeon, B., \& Aguinis, H. (2017). It's about time: New perspectives and insights on time management. Academy of Management Perspectives, 31(4), 309-330. doi: 10.5465/amp.2016.0166

Alaiyemola, F. F., Jegede, O. J., \& Okebukola, P. A. O. (1990). The effect of a metacognitive strategy of instruction on the anxiety level of students in science classes. International Journal of Science Education, 12(1), 9599. doi: 10.1080/0950069900120108

Allen, D., \& Tanner, K. (2005). Infusing active learning into the large-enrollment biology class: Seven strategies, from the simple to complex. Cel Biology Education, 4(4), 262-268. doi: 10.1187/cbe.05-08-0113

American College Health Association. (2019). National college health assessment III: Undergraduate reference group: Executive summary. Silver Spring, MD American College Health Association National College Health Assessment. Retrieved February 12, 2021, from www.acha.org/documents/ncha/NCHA -III_Fall_2019_Undergraduate_Reference_Group_Executive_Summary.pdf

Armbruster, P., Patel, M., Johnson, E., \& Weiss, M. (2009). Active learning and student-centered pedagogy improve student attitudes and performance in introductory biology. CBE-Life Sciences Education, 8(3), 203-213. doi: $10.1187 / \mathrm{cbe} .09-03-0025$

Bailey, E. G., Jensen, J., Nelson, J., Wiberg, H. K., \& Bell, J. D. (2017). Weekly Formative Exams and Creative Grading Enhance Student Learning in an Introductory Biology Course. CBE-Life Sciences Education, 16(1), ar2.

Baker, J. D. (2004). An investigation of relationships among instructor immediacy and affective and cognitive learning in the online classroom. Internet and Higher Education, 7(1), 1-13. doi: 10.1016/j.iheduc.2003.11.006

Ballen, C. J., Salehi, S., \& Cotner, S. (2017). Exams disadvantage women in introductory biology. PLOS ONE, 12(10), e0186419. doi: 10.1371/journal pone.0186419

Bamber, M. D., \& Kraenzle Schneider, J. (2016). Mindfulness-based meditation to decrease stress and anxiety in college students: A narrative synthesis of the research. Educational Research Review, 18, 1-32. doi: 10.1016/j.edurev.2015.12.004

Banas, J., Dunbar, N., Rodriguez, D., \& Liu, S. J. (2011). A review of humor in educational settings: Four decades of research. Communication Education, 60(1), 115-144

Barker, S. B., Barker, R. T., McCain, N. L., \& Schubert, C. M. (2016). A randomized cross-over exploratory study of the effect of visiting therapy dogs on college student stress before final exams. Anthrozoös, 29(1), 35-46. doi: 10.1080/08927936.2015.1069988

Beiter, R., Nash, R., McCrady, M., Rhoades, D., Linscomb, M., Clarahan, M., \& Sammut, S. (2015). The prevalence and correlates of depression, anxiety, and stress in a sample of college students. Journal of Affective Disorders, 173, 90-96. doi: 10.1016/j.jad.2014.10.054

Bekelja Wanzer, M., Bainbridge Frymier, A., Wojtaszczyk, A. M., \& Smith, T. (2006). Appropriate and inappropriate uses of humor by teachers. Communication Education, 55(2),178-196. doi:10.1080/03634520600566132

Berk, R. A. (1996). Student ratings of 10 strategies for using humor in college teaching. Journal on Excellence in College Teaching, 7(3), 71-92.

Berk, R. A. (2010). Does humor in course tests reduce anxiety and improve performance? College Teaching, 48(4), 151-158. doi: 10.1080/ 87567550009595834

Binning, K. R., Kaufmann, N., McGreevy, E. M., Fotuhi, O., Chen, S., Marshman, E., ... \& Singh, C. (2020). Changing social contexts to foster equity in college science courses: An ecological-belonging intervention. Psychological Science, 31(9), 1059-1070. doi: 10.1177/0956797620929984

Bosson, J. K., Haymovitz, E. L., \& Pinel, E. C. (2004). When saying and doing diverge: The effects of stereotype threat on self-reported versus non-verbal anxiety. Journal of Experimental Social Psychology, 40(2), 247-255. doi: 10.1016/S0022-1031(03)00099-4

Brigati, J. R., England, B. J., \& Schussler, E. E. (2020). How do undergraduates cope with anxiety resulting from active learning practices in introductory biology? PLOS ONE. doi: 10.1371/journal.pone.0236558

Broeckelman-Post, M., Johnson, A., \& Schwebach, J. R. (2016). Calling on students using notecards: Engagement and countering communication anxiety in large lecture. Journal of College Science Teaching, 45(5), 27-33.

Bruch, M. A. (1981). Relationship of test-taking strategies to test anxiety and performance: Toward a task analysis of examination behavior. Cognitive Therapy and Research, 5(1), 41-56. doi: 10.1007/BF01172325
Cadinu, M., Maass, A., Frigerio, S., Impagliazzo, L., \& Latinotti, S. (2003). Stereotype threat: The effect of expectancy on performance. European Journal of Social Psychology, 33(2), 267-285. doi: 10.1002/ejsp.145

Cavanagh, A. J., Chen, X., Bathgate, M., Frederick, J., Hanauer, D. I., \& Graham, M. J. (2018). Trust, growth mindset, and student commitment to active learning in a college science course. CBE-Life Sciences Education, 17(1), ar10. doi: 10.1187/cbe.17-06-0107

Chang, Y., \& Brickman, P. (2018). When group work doesn't work: Insights from students. CBE-Life Sciences Education, 17(3), ar52. doi: 10.1187/ cbe.17-09-0199

Chapman, K. J., \& Auken, S. V. (2001). Creating positive group project experiences: An examination of the role of the instructor on students' perceptions of group projects. Journal of Marketing Education, 23(2), 117.

Cizek, G. J., \& Burg, S. S. (2006). Addressing test anxiety in a high-stakes environment: Strategies for classrooms and schools. Thousand Oaks, CA: Corwin Press.

Claro, S., Paunesku, D., \& Dweck, C. S. (2016). Growth mindset tempers the effects of poverty on academic achievement. Proceedings of the $\mathrm{Na}$ tional Academy of Sciences USA, 113(31), 8664-8668. doi: 10.1073/ pnas.1608207113

Cohen, G. L., Garcia, J., Apfel, N., \& Master, A. (2006). Reducing the racial achievement gap: A social-psychological intervention. Science 313(5791), 1307-1310. doi: 10.1126/science.1128317

Cohen, M., Buzinski, S. G., Armstrong-Carter, E., Clark, J., Buck, B., \& Reuman, L. (2019). Think, pair, freeze: The association between social anxiety and student discomfort in the active learning environment. Scholarship of Teaching and Learning in Psychology, 5(4), 265-277. doi: 10.1037/stl0000147

Cooper, K. M., Auerbach, A. J. J., Bader, J. D., Beadles-Bohling, A. S., Brashears, J. A., Cline, E., ... \& Brownell, S. E. (2020). Fourteen recommendations to create a more inclusive environment for LGBTQ+ individ uals in academic biology. CBE-Life Sciences Education, 19(3), es6. doi 10.1187/cbe.20-04-0062

Cooper, K. M., \& Brownell, S. E. (2016). Coming out in class: Challenges and benefits of active learning in a biology classroom for LGBTQIA students. CBE-Life Sciences Education, 15(3), ar37. doi: 10.1187/cbe.16-01-0074

Cooper, K. M., \& Brownell, S. E. (2020). Student anxiety and fear of negative evaluation in active learning science classrooms. In Mintzes, J. J., \& Walter, E. M. (Eds.), Active learning in college science: The case for evidence-based practice (pp. 909-925). Cham, Switzerland: Springer International. doi: 10.1007/978-3-030-33600-4_56

Cooper, K. M., Downing, V. R., \& Brownell, S. E. (2018a). The influence of active learning practices on student anxiety in large-enrollment college science classrooms. International Journal of STEM Education, 5(1), 23. doi: 10.1186/s40594-018-0123-6

Cooper, K. M., Haney, B., Krieg, A., \& Brownell, S. E. (2017). What's in a name? The importance of students perceiving that an instructor knows their names in a high-enrollment biology classroom. CBE-Life Sciences Education, 16(1), ar8. doi: 10.1187/cbe.16-08-0265

Cooper, K. M., Hendrix, T., Stephens, M. D., Cala, J. M., Mahrer, K., Krieg, A., ... \& Brownell, S. E. (2018b). To be funny or not to be funny: Gender differences in student perceptions of instructor humor in college science courses. PLOS ONE, 13(8), e0201258. doi: 10.1371/journal.pone .0201258

Cooper, K. M., Nadile, E. M., \& Brownell, S. E. (2020). Don't joke about me: Student identities and perceptions of instructor humor in college science courses. J Microbiology and Biology Education 21(1), 21.1.21.

Creasey, G., Jarvis, P., \& Knapcik, E. (2009). A measure to assess student-instructor relationships. International Journal for the Scholarship of Teaching and Learning, 3(2), ar14. doi: 10.20429/ijsotl.2009.030214

Creswell, J. D., Welch, W. T., Taylor, S. E., Sherman, D. K., Gruenewald, T. L., \& Mann, T. (2005). Affirmation of personal values buffers neuroendocrine and psychological stress responses. Psychological Science, 16(11), 846851. doi: 10.1111/j.1467-9280.2005.01624.x

Croizet, J.-C., \& Claire, T. (1998). Extending the concept of stereotype threat to social class: The intellectual underperformance of students from low socioeconomic backgrounds. Personality and Social Psychology Bulletin, 24(6), 588-594. doi: 10.1177/0146167298246003

Czech, S. J., Katz, A. M., \& Orsillo, S. M. (2011). The effect of values affirmation on psychological stress. Cognitive Behaviour Therapy, 40(4), 304-312 doi: 10.1080/16506073.2011.585347 
Di Placito-De Rango, M. L. (2018). Situating the post-secondary instructor in a supportive role for the mental health and well-being of students. International Journal of Mental Health and Addiction, 16(2), 284-290. doi: 10.1007/s11469-017-9740-4

Dobmeier, R. A., Kalkbrenner, M. T., Hill, T. L., \& Hernández, T. J. (2013) Residential community college student awareness of mental health problems and resources. CSPA-NYS Journal of Student Affairs, 13(2), $15-28$

Doherty, J. H., \& Wenderoth, M. P. (2017). Implementing an expressive writing intervention for test anxiety in a large college course. Journal of Microbiology \& Biology Education, 18(2). doi: 10.1128/jmbe.v18i2.1307

Downing, V. R., Cooper, K. M., Cala, J. M., Gin, L. E., \& Brownell, S. E. (2020). Fear of negative evaluation and student anxiety in community college active-learning science courses. CBE-Life Sciences Education, 19(2), ar20. doi: 10.1187/cbe.19-09-0186

Driessen, E. P., Knight, J. K., Smith, M. K., \& Ballen, C. J. (2020). Demystifying the meaning of active learning in postsecondary biology education CBE-Life Sciences Education, 19(4), ar52. doi: 10.1187/cbe.20-04-0068

Durning, S. J., Dong, T., Ratcliffe, T., Schuwirth, L., Artino, A. R., Boulet, J. R. \& Eva, K. (2016). Comparing open-book and closed-book examinations: A systematic review. Academic Medicine, 91(4), 583-599. doi: 10.1097/ ACM.0000000000000977

Dweck, C. S. (2000). Self-Theories: Their Role in Motivation, Personality, and Development. Psychology, Philadelphia.

Edlund, J. E. (2020). Exam wrappers in psychology. Teaching of Psychology, 47(2), 156-161. doi: 10.1177/0098628320901385

Eisenberg, D., Downs, M. F., Golberstein, E., \& Zivin, K. (2009). Stigma and help seeking for mental health among college students. Medical Care Research and Review, 66(5), 522-541. doi: 10.1177/1077558709335173

Eisenberg, D., Hunt, J., \& Speer, N. (2013). Mental health in American colleges and universities: Variation across student subgroups and across campuses. Journal of Nervous and Mental Disease, 201(1), 60-67. doi: 10.1097/ NMD.0b013e31827ab077

Ellis, J. M., Powell, C. S., Demetriou, C. P., Huerta-Bapat, C., \& Panter, A. T. (2019). Examining first-generation college student lived experiences with microaggressions and microaffirmations at a predominately white public research university. Cultural Diversity \& Ethnic Minority Psychology. 25(2), 266-279. doi: 10.1037/cdp0000198

Embse, N. von der, Barterian, J., \& Segool, N. (2013). Test anxiety interventions for children and adolescents: A systematic review of treatment studies from 2000-2010. Psychology in the Schools, 50(1), 57-71. doi: $10.1002 /$ pits. 21660

England, B. J., Brigati, J. R., \& Schussler, E. E. (2017). Student anxiety in introductory biology classrooms: Perceptions about active learning and persistence in the major. PLOS ONE, 12(8), e0182506. doi: $10.1371 /$ journal .pone.0182506

England, B. J., Brigati, J. R., Schussler, E. E., \& Chen, M. M. (2019). Student anxiety and perception of difficulty impact performance and persistence in introductory biology courses. CBE-Life Sciences Education, 18(2) ar21. doi: $10.1187 / \mathrm{cbe} .17-12-0284$

Erbe, B. (2007). Reducing test anxiety while increasing learning: The cheat sheet. College Teaching, 55(3), 96-98. doi: 10.3200/CTCH.55.3.96-98

Estrada, M., Young, G. R., Nagy, J., Goldstein, E. J., Ben-Zeev, A., MárquezMagaña, L., \& Eroy-Reveles, A. (2019). The Influence of Microaffirmations on Undergraduate Persistence in Science Career Pathways. CBE-Life Sciences Education, 18(3), ar40.

Everson, H. T., Smodlaka, I., \& Tobias, S. (1994). Exploring the relationship of test anxiety and metacognition on reading test performance: A cognitive analysis.Anxiety, Stress, \&Coping,7(1), 85-96. doi:10.1080/10615809408248395

Fernandez, O. E. (2020). Second chance grading: An equitable, meaningful, and easy-to-implement grading system that synergizes the research on testing for learning, mastery grading, and growth mindsets. Problems, Resources, and Issues in Mathematics Undergraduate Studies, 1-14 https://www.tandfonline.com/doi/full/10.1080/10511970.2020.1772915

Frattaroli, J., Thomas, M., \& Lyubomirsky, S. (2011). Opening up in the classroom: Effects of expressive writing on graduate school entrance exam performance. Emotion, 11(3), 691-696. doi: 10.1037/a0022946

Freeman, S., Eddy, S. L., McDonough, M., Smith, M. K., Okoroafor, N., Jordt, H., \& Wenderoth, M. P. (2014). Active learning increases student performance in science, engineering, and mathematics. Proceedings of the National Academy of Sciences USA, 111(23), 8410-8415. doi: 10.1073/ pnas.1319030111

Garlow, S. J., Rosenberg, J., Moore, J. D., Haas, A. P., Koestner, B., Hendin, H., \& Nemeroff, C. B. (2008). Depression, desperation, and suicidal ideation in college students: Results from the American Foundation for Suicide Prevention College Screening Project at Emory University. Depression and Anxiety, 25(6), 482-488. doi: 10.1002/da.20321

Gezer-Templeton, P. G., Mayhew, E. J., Korte, D. S., \& Schmidt, S. J. (2017). Use of exam wrappers to enhance students' metacognitive skills in a large introductory food science and human nutrition course. Journal of Food Science Education, 16(1), 28-36. doi: 10.1111/1541-4329.12103

Gharib, A., \& Phillips, W. (2012). Test anxiety and performance on open book and cheat sheet exams in introductory psychology. International Proceedings of Economics Development and Research, 53(1).

Haak, D. C., HilleRisLambers, J., Pitre, E., \& Freeman, S. (2011). Increased structure and active learning reduce the achievement gap in introductory biology. Science, 332(6034), 1213-1216. doi: 10.1126/science.1204820

Häfner, A., Oberst, V., \& Stock, A. (2014a). Avoiding procrastination through time management: An experimental intervention study. Educational Studies, 40(3), 352-360. doi: 10.1080/03055698.2014.899487

Häfner, A., \& Stock, A. (2010). Time management training and perceived control of time at work. Journal of Psychology, 144(5), 429-447. doi: 10.1080/00223980.2010.496647

Häfner, A., Stock, A., Pinneker, L., \& Ströhle, S. (2014b). Stress prevention through a time management training intervention: An experimental study. Educational Psychology, 34(3), 403-416. doi: 10.1080/01443410 2013.785065

Harris, R. B., Grunspan, D. Z., Pelch, M. A., Fernandes, G., Ramirez, G., \& Freeman, S. (2019). Can test anxiety interventions alleviate a gender gap in an undergraduate STEM course? CBE-Life Sciences Education, 18(3), ar35 doi: $10.1187 / \mathrm{cbe} .18-05-0083$

Harrison, C., \& Tanner, K. D. (2018). Language matters: Considering microaggressions in science. CBE-Life Sciences Education, 17(1), fe4. doi 10.1187/cbe.18-01-0011

Hattie, J., Biggs, J., \& Purdie, N. (1996). Effects of learning skills interventions on student learning: A meta-analysis. Review of Educational Research, 66(2), 99-136. doi: 10.3102/00346543066002099

Henning, J. A., Ballen, C. J., Molina, S. A., \& Cotner, S. (2019). Hidden identities shape student perceptions of active learning environments. Frontiers in Education, 4, 129. doi: 10.3389/feduc.2019.00129

Henry, M. A., Shorter, S., Charkoudian, L., Heemstra, J. M., \& Corwin, L. A. (2019). FAIL is not a four-letter word: A theoretical framework for exploring undergraduate students' approaches to academic challenge and responses to failure in STEM learning environments. CBE-Life Sciences Education, 18(1), ar11. doi: 10.1187/cbe.18-06-0108

Hodges, L. C. (2018). Contemporary issues in group learning in undergraduate science classrooms: A perspective from student engagement. CBELife Sciences Education, 17(2), es3. doi: 10.1187/cbe.17-11-0239

Jaasma, M. A., \& Koper, R. J. (1999). The relationship of student-faculty outof-class communication to instructor immediacy and trust and to student motivation. Communication Education, 48(1), 41-47. doi: 10.1080/ 03634529909379151

Jamieson, J. P., Mendes, W. B., \& Nock, M. K. (2013). Improving acute stress responses: The power of reappraisal. Current Directions in Psychological Science, 22(1), 51-56. doi: 10.1177/0963721412461500

Jamieson, J. P., Peters, B. J., Greenwood, E. J., \& Altose, A. J. (2016). Reappraising stress arousal improves performance and reduces evaluation anxiety in classroom exam situations. Social Psychological and Personality Science, 7(6), 579-587. doi: 10.1177/1948550616644656

Jarolmen, J., \& Patel, G. (2018). The effects of animal-assisted activities on college students before and after a final exam. Journal of Creativity in Mental Health, 13(3), 264-274. doi: 10.1080/15401383.2018.1425941

Jegede, O. J., Alaiyemola, F. F., \& Okebukola, P. A. O. (1990). The effect of concept mapping on students' anxiety and achievement in biology. Journal of Research in Science Teaching, 27(10), 951-960. doi: 10.1002/ tea.3660271004

Jensen, J. L., \& Lawson, A. (2011). Effects of collaborative group composition and inquiry instruction on reasoning gains and achievement in 
undergraduate biology. CBE-Life Sciences Education, 10(1), 64-73. doi: 10.1187/cbe.10-07-0089

Johns, M., Schmader, T., \& Martens, A. (2005). Knowing is half the battle: Teaching stereotype threat as a means of improving women's math performance. Psychological Science, 16(3),175-179. doi:10.1111/j.0956-7976 2005.00799.x

Jordt, H., Eddy, S. L., Brazil, R., Lau, I., Mann, C., Brownell, S. E., ... \& Freeman S. (2017). Values affirmation intervention reduces achievement gap between underrepresented minority and white students in introductory biology classes. CBE-Life Sciences Education, 16(3), ar41. doi: 10.1187/ cbe.16-12-0351

Juvonen, J., Lessard, L. M., Rastogi, R., Schacter, H. L., \& Smith, D. S. (2019). Promoting social inclusion in educational settings: Challenges and opportunities. Educational Psychologist, 54(4), 250-270. doi: 10.1080/ 00461520.2019 .1655645

Kelly, S., Rice, C., Wyatt, B., Ducking, J., \& Denton, Z. (2015). Teacher immediacy and decreased student quantitative reasoning anxiety: The mediating effect of perception. Communication Education, 64(2), 171-186. doi: 10.1080/03634523.2015.1014383

Kimbark, K., Peters, M. L., \& Richardson, T. (2017). Effectiveness of the student success course on persistence, retention, academic achievement, and student engagement. Community College Journal of Research and Practice, 41(2), 124-138. doi: 10.1080/10668926.2016.1166352

Koch, C. J., \& Kleinmann, M. (2002). A stitch in time saves nine: Behavioural decision-making explanations for time management problems. European Journal of Work and Organizational Psychology, 11(2), 199-217. doi: 10.1080/13594320244000120

Kohli, R., \& Solórzano, D. G. (2012). Teachers, please learn our names! Racial microagressions and the $\mathrm{K}-12$ classroom. Race Ethnicity and Education, 15(4), 441-462. doi: 10.1080/13613324.2012.674026

Kritzinger, A., Lemmens, J.-C., \& Potgieter, M. (2018). Learning strategies for first-year biology: Toward moving the "murky middle." CBE-Life Sciences Education, 17(3), ar42. doi: 10.1187/cbe.17-10-0211

Kruger, L. J., Wandle, C., \& Struzziero, J. (2007). Coping with the stress of high stakes testing. Journal of Applied School Psychology, 23(2), 109 128. doi: 10.1300/J370v23n02_07

Kumaraswamy, N. (2013). Academic stress, anxiety and depression among college students-A brief review. International Review of Social Sciences and Humanities, 5(1), 135-143.

LaCaille, R. A., LaCaille, L. J., \& Maslowski, A. K. (2019). Metacognition, course performance, and perceived competence for learning: An examination of quiz and exam wrappers. Scholarship of Teaching and Learning in Psychology, 5(3), 209-222. doi: 10.1037/stl0000114

Langdon, J., Botnaru, D. T., Wittenberg, M., Riggs, A. J., Mutchler, J., Syno, M. \& Caciula, M. C. (2019). Examining the effects of different teaching strategies on metacognition and academic performance. Advances in Physiology Education, 43(3), 414-422. doi: 10.1152/advan.00013.2018

Lazarus, R. S., \& Folkman, S. (1984). Stress, appraisal, and coping. New York: Springer.

LeFebvre, L., \& Allen, M. (2014). Teacher immediacy and student learning: An examination of lecture/laboratory and self-contained course sections. Journal of the Scholarship of Teaching and Learning, 29-45. doi 10.14434/josotl.v14i2.4002

Lipson, S. K., Lattie, E. G., \& Eisenberg, D. (2018). Increased rates of mental health service utilization by U.S. college students: 10-year population-level trends (2007-2017). Psychiatric Services, 70(1), 60-63. doi 10.1176/appi.ps.201800332

Lo, S. M., Gardner, G. E., Reid, J., Napoleon-Fanis, V., Carroll, P., Smith, E., \& Sato, B. K. (2019). Prevailing questions and methodologies in biology education research: A longitudinal analysis of research in CBE-Life Sciences Education and at the Society for the Advancement of Biology Education Research. CBE-Life Sciences Education, 18(1), ar9. doi: 10.1187/ cbe.18-08-0164

Macan, T. H., Shahani, C., Dipboye, R. L., \& Phillips, A. P. (1990). College students' time management: Correlations with academic performance and stress. Journal of Educational Psychology, 82(4), 760-768. doi: 10.1037/0022-0663.82.4.760

Madlung, A., Bremer, M., Himelblau, E., \& Tullis, A. (2011). A study assessing the potential of negative effects in interdisciplinary math-biology instruction. CBE-Life Sciences Education, 10(1), 43-54. doi: 10.1187/cbe.10-08-0102
Mahmoud, J. S. R., Staten, R. T., Hall, L. A., \& Lennie, T. A. (2012). The relationship among young adult college students' depression, anxiety, stress, demographics, life satisfaction, and coping styles. Issues in Mental Health Nursing, 33(3), 149-156. doi: 10.3109/01612840.2011.632708

Mak, B. (2011). An exploration of speaking-in-class anxiety with Chinese ESL learners. System, 39(2), 202-214. doi: 10.1016/j.system.2011.04.002

Matthews, G., Hillyard, E. J., \& Campbell, S. E. (1999). Metacognition and maladaptive coping as components of test anxiety. Clinical Psychology \& Psychotherapy, 6(2), 111-125. doi: 10.1002/(SICI)1099-0879(199905)6:2 $<111:$ AID-CPP192>3.0.CO;2-4

May, R. W., \& Casazza, S. P. (2012). Academic major as a perceived stress indicator: Extending stress management intervention. College Student Journal, 46(2), 264-274

Mazer, J. P., McKenna-Buchanan, T. P., Quinlan, M. M., \& Titsworth, S. (2014). The dark side of emotion in the classroom: Emotional processes as mediators of teacher communication behaviors and student negative emotions. Communication Education, 63(3), 149-168. doi: 10.1080/03634523.2014.904047

McDonald, S., McDonald, E., \& Roberts, A. (2017). Effects of novel dog exposure on college students' stress prior to examination. North American Journal of Psychology, 19(2), 477-484.

Mitchell, S. L., Darrow, S. A., Haggerty, M., Neill, T., Carvalho, A., \& Uschold, C. (2012). Curriculum infusion as college student mental health promotion strategy. Journal of College Student Psychotherapy, 26(1), 22-38. doi: 10.1080/87568225.2012.633038

Miyake, A., Kost-Smith, L. E., Finkelstein, N. D., Pollock, S. J., Cohen, G. L., \& Ito, T. A. (2010). Reducing the gender achievement gap in college science: A classroom study of values affirmation. Science, 330(6008) 1234-1237. doi: 10.1126/science.1195996

Moore, R., \& Jensen, P. A. (2007). Do open-book exams impede long-term learning in introductory biology courses? Journal of College Science Teaching, 36(7), 46.

Morey, T., \& Taylor, N. (2019). Understanding how undergraduate students experience and manage stress: Implications for teaching and learning anthropology. Teaching and Learning Anthropology, 2(2), 41-61. doi: 10.5070/T32240875

Muller, K., Nyman, M., Squadere, J., Feuer, E., Sokolowski, K., \& Rotella, L. (2017). Examining predictors of first year college student retention. New York Journal of Student Affairs, 17(1), 3-14.

Myers, S. B., Sweeney, A. C., Popick, V., Wesley, K., Bordfeld, A., \& Fingerhut R. (2012). Self-care practices and perceived stress levels among psychology graduate students. Training and Education in Professional Psychology, 6(1), 55-66. doi: 10.1037/a0026534

Neumann, D. L., Hood, M., \& Neumann, M. M. (2009). Statistics? You must be joking: The application and evaluation of humor when teaching statistics. Journal of Statistics Education, 17(2). doi: 10.1080/10691898.2009 11889525

Nonis, S. A., Hudson, G. I., Logan, L. B., \& Ford, C. W. (1998). Influence of perceived control over time on college students' stress and stress-related outcomes. Research in Higher Education, 39(5), 587-605. doi: 10.1023/A:1018753706925

Okebukola, P. A., \& Jegede, O. J. (1989). Students' anxiety towards and perception of difficulty of some biological concepts under the concept-mapping heuristic. Research in Science \& Technological Education 7(1), 85-92. doi: 10.1080/0263514890070109

Osborne, J. W. (2001). Testing stereotype threat: Does anxiety explain race and sex differences in achievement? Contemporary Educational Psychology, 26(3), 291-310. doi: 10.1006/ceps.2000.1052

Osborne, J. W. (2007). Linking stereotype threat and anxiety. Educational Psychology, 27(1), 135-154. doi: 10.1080/01443410601069929

Osterhage, J. L., Usher, E. L., Douin, T. A., \& Bailey, W. M. (2019). Opportunities for self-evaluation increase student calibration in an introductory biology course. CBE-Life Sciences Education, 18(2), ar16. doi: 10.1187/ cbe.18-10-0202

Osueke, B., Mekonnen, B., \& Stanton, J. D. (2018). How undergraduate science students use learning objectives to study. Journal of Microbiology \& Biology Education, 19(2). doi: 10.1128/jmbe.v19i2.1510

Park, D., Ramirez, G., \& Beilock, S. L. (2014). The role of expressive writing in math anxiety. Journal of Experimental Psychology: Applied, 20(2), $103-$ 111. doi: $10.1037 /$ xap0000013 
Pate, A., Lafitte, E. M., Ramachandran, S., \& Caldwell, D. J. (2019). The use of exam wrappers to promote metacognition. Currents in Pharmacy Teaching and Learning, 11(5), 492-498. doi: 10.1016/j.cptl.2019.02.008

Peters, E., Shoots-Reinhard, B., Tompkins, M. K., Schley, D., Meilleur, L., Sinayev, A., ... \& Crocker, J. (2017). Improving numeracy through values affirmation enhances decision and STEM outcomes. PLOS ONE, 12(7), e0180674. doi: 10.1371/journal.pone.0180674

Posselt, J. R., \& Lipson, S. K. (2016). Competition, anxiety, and depression in the college classroom: Variations by student identity and field of study. Journal of College Student Development, 57(8), 973-989.

Powers, M. D. (2015). Growth mindset intervention at the community college level: A multiple methods examination of the effects on faculty and students. UCLA. Retrieved February 12, 2021, from https://escholarship.org/ uc/item/48575763

Putwain, D. (2008). Do examinations stakes moderate the test anxiety-examination performance relationship? Educational Psychology, 28(2), 109-118. doi: 10.1080/01443410701452264

Ramirez, G., \& Beilock, S. L. (2011). Writing about testing worries boosts exam performance in the classroom. Science, 331(6014), 211-213. doi: 10.1126/science.1199427

Rawson, H. E., Bloomer, K., \& Kendall, A. (1994). Stress, anxiety, depression, and physical illness in college students. Journal of Genetic Psychology, 155(3), 321-330. doi: 10.1080/00221325.1994.9914782

Regehr, C., Glancy, D., \& Pitts, A. (2013). Interventions to reduce stress in university students: A review and meta-analysis. Journal of Affective Disorders, 148(1), 1-11. doi: 10.1016/j.jad.2012.11.026

Ribeiro, I. J. S., Pereira, R., Freire, I. V., de Oliveira, B. G., Casotti, C. A., \& Boery, E. N. (2018). Stress and quality of life among university students: A systematic literature review. Health Professions Education, 4(2), 70-77. doi: 10.1016/j.hpe.2017.03.002

Roediger, H. L., III, \& Karpicke, J. D. (2006). Test-enhanced learning: Taking memory tests improves long-term retention. Psychological Science, 17(3), 249-255. doi: 10.1111/j.1467-9280.2006.01693.x

Rosser, S. V. (1998). Group work in science, engineering, and mathematics: Consequences of ignoring gender and race. College Teaching, 46(3), 82-88.

Sabel, J. L., Dauer, J. T., \& Forbes, C. T. (2017). Introductory biology students' use of enhanced answer keys and reflection questions to engage in metacognition and enhance understanding. CBE-Life Sciences Education, 16(3), ar40. doi: 10.1187/cbe.16-10-0298

Sato, B. K., He, W., Warschauer, M., \& Kadandale, P. (2015). The grass isn't always greener: Perceptions of and performance on open-note exams. CBE-Life Sciences Education, 14(2), ar11. doi: 10.1187/cbe.14-08-0121

Schinske, J. N., Balke, V. L., Bangera, M. G., Bonney, K. M., Brownell, S. E., Carter, R. S., ... \& Corwin, L. A. (2017). Broadening participation in biology education research: Engaging community college students and faculty. CBE-Life Sciences Education, 16(2), mr1. doi: 10.1187/cbe.16-10-0289

Schleider, J., \& Weisz, J. (2018). A single-session growth mindset intervention for adolescent anxiety and depression: 9-month outcomes of a randomized trial. Journal of Child Psychology and Psychiatry, 59(2), 160-170. doi: $10.1111 /$ jcpp.12811

Schleider, J. L., \& Weisz, J. R. (2016). Reducing risk for anxiety and depression in adolescents: Effects of a single-session intervention teaching that personality can change. Behaviour Research and Therapy, 87, 170-181. doi: 10.1016/j.brat.2016.09.011

Schroder, H. S., Yalch, M. M., Dawood, S., Callahan, C. P., Brent Donnellan, M., \& Moser, J. S. (2017). Growth mindset of anxiety buffers the link between stressful life events and psychological distress and coping strategies. Personality and Individual Differences, 110, 23-26. doi: 10.1016/j. paid.2017.01.016

Schutt, M., Allen, B. S., \& Laumakis, M. A. (2009). The effects of instructor immediacy behaviors in online learning environments. Quarterly Review of Distance Education, 10(2), 135-148.

Sebesta, A. J., \& Bray Speth, E. (2017). How should I study for the exam? Self-regulated learning strategies and achievement in introductory biology. CBE-Life Sciences Education, 16(2), ar30. doi: 10.1187/cbe.16-09-0269

Seidel, S. B., Reggi, A. L., Schinske, J. N., Burrus, L. W., \& Tanner, K. D. (2015). Beyond the biology: A systematic investigation of noncontent instructor talk in an introductory biology course. CBE-Life Sciences Education, 14(4), ar43. doi: 10.1187/cbe.15-03-0049
Seidel, S. B., \& Tanner, K. D. (2013). "What if students revolt?"-Considering student resistance: Origins, options, and opportunities for investigation. CBELife Sciences Education, 12(4), 586-595. doi: 10.1187/cbe-13-09-0190

Smith, M., Chen, Y., Berndtson, R., Burson, K., \& Griffin, W. (2017). "Office hours are kind of weird": Reclaiming a resource to foster student-faculty interaction. InSight: A Journal of Scholarly Teaching, 12, 14-29. doi: 10.46504/12201701sm

Spada, M. M., Nikcevic, A. V., Moneta, G. B., \& Ireson, J. (2006). Metacognition as a mediator of the effect of test anxiety on a surface approach to studying. Educational Psychology, 26(5), 615-624. doi: 10.1080/01443410500390673

Spencer, S. J., Steele, C. M., \& Quinn, D. M. (1999). Stereotype threat and women's math performance. Journal of Experimental Social Psychology, 35(1), 4-28. doi: 10.1006/jesp.1998.1373

Stains, M., \& Vickrey, T. (2017). Fidelity of implementation: An overlooked yet critical construct to establish effectiveness of evidence-based instructional practices. CBE-Life Sciences Education, 16(1), rm1. doi: 10.1187/ cbe.16-03-0113

Stanton, J. D., Dye, K. M., \& Johnson, M. (2019). Knowledge of learning makes a difference: A comparison of metacognition in introductory and senior-level biology students. CBE-Life Sciences Education, 18(2), ar24. doi: $10.1187 / \mathrm{cbe} .18-12-0239$

Steele, C. M., \& Aronson, J. (1995). Stereotype threat and the intellectual test performance of African Americans. Journal of Personality and Social Psychology, 69(5), 797-811. doi: 10.1037/0022-3514.69.5.797

Steele-Johnson, D., \& Kalinoski, Z. T. (2014). Error framing effects on performance: Cognitive, motivational, and affective pathways. Journal of Psychology, 148(1), 93-111. doi: 10.1080/00223980.2012.748581

Strauss, P., U-Mackey, A., \& Young, S. (2011). "I know the type of people I work well with": Student anxiety in multicultural group projects. Studies in Higher Education, 36(7), 815-829. doi: 10.1080/03075079.2010.488720

Tanner, K. D. (2013). Structure matters: Twenty-one teaching strategies to promote student engagement and cultivate classroom equity. CBE-Life Sciences Education 12(3), 322-331.

Teven, J. J. (2001). The relationships among teacher characteristics and perceived caring. Communication Education, 50(2), 159-169. doi: 10.1080/03634520109379241

Theobald, E. J., Eddy, S. L., Grunspan, D. Z., Wiggins, B. L., \& Crowe, A. J. (2017). Student perception of group dynamics predicts individual performance: Comfort and equity matter. PLOS ONE, 12(7), e0181336. doi: 10.1371/journal.pone.0181336

Theobald, E. J., Hill, M. J., Tran, E., Agrawal, S., Arroyo, E. N., Behling, S., ... \& Freeman, S. (2020). Active learning narrows achievement gaps for underrepresented students in undergraduate science, technology, engineering, and math. Proceedings of the National Academy of Sciences USA, 117(12), 6476-6483. doi: 10.1073/pnas.1916903117

Trammell, J. P. (2017). The effect of therapy dogs on exam stress and memory. Anthrozoös, 30(4), 607-621. doi: 10.1080/08927936.2017.1370244

Walck-Shannon, E. M., Cahill, M. J., McDaniel, M. A., \& Frey, R. F. (2019). Participation in voluntary re-quizzing is predictive of increased performance on cumulative assessments in introductory biology. CBE-Life Sciences Education, 18(2), ar15. doi: 10.1187/cbe.18-08-0163

Wanzer, M. B., \& Frymier, A. B. (1999). The relationship between student perceptions of instructor humor and students' reports of learning. Communication Education, 48(1), 48-62. doi: 10.1080/03634529909379152

Watson, D., \& Friend, R. (1969). Measurement of social-evaluative anxiety. Journal of Consulting and Clinical Psychology, 33(4), 448-457. doi: 10.1037/h0027806

Waugh, A. H., \& Andrews, T. C. (2020). Diving into the details: Constructing a framework of random call components. CBE-Life Sciences Education, 19(2), ar14. doi: 10.1187/cbe.19-07-0130

Weeks, J. W., Heimberg, R. G., Fresco, D. M., Hart, T. A., Turk, C. L., Schneier, F. R., \& Liebowitz, M. R. (2005). Empirical validation and psychometric evaluation of the brief fear of negative evaluation scale in patients with social anxiety disorder. Psychological Assessment, 17(2), 179-190.

White, A., \& LaBelle, S. (2019). A qualitative investigation of instructors' perceived communicative roles in students' mental health management. Communication Education, 68(2), 133-155. doi: 10.1080/03634523.2019.1571620

Williams, A. S. (2010). Statistics anxiety and instructor immediacy. Journal of Statistics Education, 18(2). doi: 10.1080/10691898.2010.11889495 
Wilson, K. J., Brickman, P., \& Brame, C. J. (2018). Group work. CBE-Life Sciences Education, 17(1), fe1. doi: 10.1187/cbe.17-12-0258

Wittmaier, B. C. (1972). Test anxiety and study habits. Journal of Educational Research, 65(8), 352-354. doi: 10.1080/00220671.1972.10884344

Wu, I. H. C., Bathje, G. J., Kalibatseva, Z., Sung, D., Leong, F. T. L., \& Collins-Eaglin, J. (2017). Stigma, mental health, and counseling service use: A person-centered approach to mental health stigma profiles. Psychological Services, 14(4), 490-501. doi: 10.1037/ser0000165

Yeager, D. S., Hanselman, P., Walton, G. M., Murray, J. S., Crosnoe, R., Muller, C., ... \& Dweck, C. S. (2019). A national experiment reveals where growth mindset improves achievement. Nature, 573(7774), 364-369. doi: 10.1038/s41586-019-1466-y

Yusufov, M., Nicoloro-SantaBarbara, J., Grey, N. E., Moyer, A., \& Lobel, M. (2019). Meta-analytic evaluation of stress reduction interventions for undergraduate and graduate students. International Journal of Stress Management, 26(2), 132-145. doi: 10.1037/str0000099

Zivin, K., Eisenberg, D., Gollust, S. E., \& Golberstein, E. (2009). Persistence of mental health problems and needs in a college student population. Journal of Affective Disorders, 117(3), 180-185. doi: 10.1016/j.jad 2009.01.001 